Article

\title{
Everyday Practices, Everyday Water: From Foucault to Rivera-Cusicanqui (with a Few Stops in between)
}

\author{
Kathryn Furlong ${ }^{1}\left(\mathbb{D}\right.$, Denisse Roca-Servat ${ }^{2}{ }^{(\mathbb{D}}$, Tatiana Acevedo-Guerrero ${ }^{3,4, *} \mathbb{C}$ and \\ María Botero-Mesa ${ }^{5}$ \\ 1 Department of Geography, Université de Montréal, Montréal, QC H2V 0B3, Canada; \\ kathryn.furlong@umontreal.ca \\ 2 School of Social Sciences, Territory Research Group, Universidad Pontificia Bolivariana, \\ P.O. Box 050031 Medellín, Colombia; denisse.roca@upb.edu.co \\ 3 IHE-Delft Institute for Water Education, 2611 AX Delft, The Netherlands \\ 4 Department of Geography, Planning and International Development Studies, University of Amsterdam, \\ 1018 WV Amsterdam, The Netherlands \\ 5 Corporación Ecológica y Cultural Penca de Sábila, P.O. Box 050012 Medellín, Colombia; bmmaria@live.com \\ * Correspondence: t.acevedo@un-ihe.org
}

Received: 17 June 2019; Accepted: 16 September 2019; Published: 30 September 2019

check for updates

\begin{abstract}
In this article, we explore elements of the literature on practices and the everyday to provide reference points for water researchers. We cast a wide net in recognition of the complex and multifaceted nature of human relationships to water that cannot be reduced to a single perspective. The article begins with the work of prominent French theorists including Foucault, Lefebvre, Bourdieu and de Certeau. Each grapples with the interrelationship between wider socio-political processes and practice in different ways. This leads us to pragmatism and non-representational theory in the second section, which argue that to understand socio-political processes, one must begin from practices. In the third section, we engage with work on practices in conditions of instability and precarity, which are widespread under contemporary conditions of post-colonial neoliberalism, and the role of "care" in mitigating their effects. In section four, we discuss the scholarship and practice of Silvia Rivera-Cusicanqui, who explores and extends many of the approaches elaborated above. The article concludes with a reflection on what this means for engaging with the multiple realities and ways of living with water.
\end{abstract}

Keywords: water; practices; everyday neoliberal precarity; care; decolonization

\section{Introduction}

This article explores a range of perspectives on practices and the everyday in an effort to provide reference points for work on governing water. We refer to governing water-as opposed to water governance or management-following Bolivian sociologist Silvia Rivera-Cusicanqui's [1] warning against the hidden effects of dominant concepts that conceal lived reality. In choosing governing, we emphasize openness in the recognition of the complex, multifaceted and contradictory nature of human relationships to water. Similarly, our engagement with scholarship on practices and the everyday does not seek to encompass all of the associated work nor to resolve the tensions between the various approaches. Rather, in putting diverse threads out there, we respond to Rivera-Cusicanqui's call to write from doubts and turmoil: observing from uncertainty in order to see possibilities that are hidden by established ways of thinking.

Still, our selection of threads is purposeful. We begin with a set of 20th century French theorists whom we include for their foundational contributions to the study of practices and the everyday. Their work has been central in academic and mainstream thinking across a range of subjects, including that of 
governing water. In this group, Foucault and Bourdieu are concerned with practices as actions linked to broader forms of power/knowledge or capital in society, reflecting and reinforcing associated patterns of dominance. Here, practices stand in contrast to the "everyday" as explored by Lefebvre and de Certeau, who are concerned with how everyday actions and reactions are constructed in society and how they might also become sites of resistance. In the second section, we build on these discussions through an engagement with pragmatism and non-representational theory, which building on the French theorists, reverse the arrow of enquiry, asking how to know practices methodologically and what this can tell us about how to understand broader questions in society. As such, while they recognize the importance of structure, the nature of its influence cannot be determined a priori. Pragmatism, in particular, has had significant influence across a range of fields, from education to linguistics, in terms of how to build on the everyday to develop knowledge and practice [2]. In the next two sections, we build on these theoretical and methodological reflections to examine how practices are mobilized under contemporary conditions of precarity. First, in section three, we integrate scholarship that grapples with practices in conditions of neoliberal instability, precarity and crisis, and the practice of "care" as one that attempts to allay its effects. Then, in the fourth section, we turn to the scholarship and practice of sociologist and activist Rivera-Cusicanqui with her concepts of weaving, fragments, unsettled contradiction, and bodily engagement as the basis of understanding and engaging in decolonizing practice. In essence, Rivera-Cusicanqui can be seen as reflecting elements of the approaches to practices and the everyday explored throughout the essay. She is concerned with the power relationships inherent in practices and how they can be destabilised through an engagement with the everyday, here practice and the everyday constitute personal political engagements that can be mobilized to redress contemporary inequalities.

Following Rivera-Cusicuanqui, we seek to "weave" rather than resolve. Drawing on Aymara thought, Rivera-Cusicanqui [1] invokes ch'ixi as central to mestizo subjectivities. Ch'ixi is like a fabric. It may begin with contrasting black and white threads, that when woven together form points that appear grey from a distance but yet regain their distinctness when approached anew. In this spirit, Rivera-Cusicanqui insists on always working with ideas in the making, from fragments, by favouring listening and learning through engagement in practice. This approach, while unique, has echoes with some of the other work explored below. It has threads in common with Lefebvre's view that practices must be approached from a dialectics of unresolved tensions that somehow form a whole [3], and with pragmatic and non-representational perspectives, which insist that knowledge must begin from practices, from the observation of the everyday and not from any pre-established theoretical perspective [4,5]. Rivera-Cusicanqui's goes further, insisting that to understand practices one must engage in them: observation is insufficient [6]. This has echoes with phronesis: one learns physically; through action, knowledge becomes embodied [7].

Thus, in the paragraphs that follow, we approach practices and the everyday through the metaphor of weaving. We offer a fabric in the making. From this approach, one can distance oneself from a dichotomous vision of the world since differences, present in fragments, can be irreconcilable and yet help to form a more complete whole. The idea is not to eliminate or deny contradictions but to take advantage of the vitality of the recombinatory process. Instead of trying to create a uniform or harmonious framework, we recognize difference, and leave it unresolved.

\section{Structure and the Everyday: From Foucault's Diffuse Power to de Certeau's Transgressive Practices}

In this section, we juxtapose some elements of the thinking on practices and the everyday of the French theorists Michel Foucault (1926-1984), Henri Lefebvre (1901-1991), Pierre Bourdieu (1930-2002) and Michel de Certeau (1925-1986). Briefly, while Foucault is concerned with practices as action linked to broader forms of power/knowledge, reflecting and reinforcing associated patterns of dominance, the authors that follow-Lefebvre, Bourdieu, and de Certeau—take great pains to distance themselves from structural and deterministic analyses. Still, within this group, at least in his later writings, Lefebvre takes a more deterministic position vis-à-vis the particular nature of society's influence on 
practice, emphasizing the confluence of government and capital through what he calls the "organized society of controlled consumption". Bourdieu, by contrast, offers the most developed framework for understanding the interaction of structure and practice through his concepts of field, capital and habitus. Yet, in not specifying the nature of the structural influence, he avoids generalisation and restricting his approach to a particular historical-geographical context. Finally, the ideas of de Certeau offer practices the most autonomous potential and thus bring us closest to the perspectives of pragmatism and non-representational theory, explored in the next section.

In his work on practices, Foucault was concerned with how they were organized through the diffusion of power in society. For Foucault, the relationship between knowledge and power is central in framing the production of and possibilities for practice. Knowledge and power are mutually constitutive since there is no power relation without a correlative field of knowledge, nor any knowledge that does not presuppose and constitute relations of power [8] (p. 88). It is power rather than any facts about reality that makes things "true". What counts as knowledge is produced through discourse, itself a product of language and practices, and all practices have a discursive aspect. Discourse refers to a set of statements that enables the creation of a particular way of thinking about a given topic. According to Foucault [9] (p. 117), "discourse in this sense is not an ideal timeless form ( ... ) it is, from beginning to end, historical—a fragment of history ( ... ) posing its own limits, its divisions, its transformations, the specific modes of its temporality". What interested Foucault "were the rules and practices that produced meaningful statements and regulated discourse" [8] (p. 44).

Discursive practices construct topics and govern the way a topic can be meaningfully discussed and reasoned. They also influence how ideas are put into practice and used to regulate the conduct of others [8] (p. 72). Here, societies are shaped by powerful and efficient apparatuses of knowledge, truth and power. The translation of specific discourses into practice yields power and produces particular subjects. Power relations cannot be established or consolidated without the production, accumulation, and circulation of an associated discourse. Still, discourses-like silences-are neither completely subservient to power nor necessarily a check upon it [10]. We must make allowances for the complex and unstable process whereby discourse can be both an instrument and an effect of power, but also a hindrance, a stumbling block, or a point of resistance [10]. For Escobar [11], "progress" and "development" are important discursive practices that have been instrumental in producing particular modes of being and thinking while disqualifying others, to the point of making them impossible.

Such disqualification of particular modes of being and thinking is a key concern in water scholarship, where Foucault's ideas have been mobilized to expose the displacement of certain practices by dominant discourses and their associated practices. Documenting the changes to everyday life introduced by colonial medical officials in Cape Town in the aftermath of the bubonic plague, Swanson [12] analyses how discourses of sanitation and hygiene displaced not only certain practices but also entire black populations forming the basis for segregation policies. Other discourses central in transforming both the ways of governing water and community water practices include those of hygiene and "the sanitary city" [13], modernity [14], development [15], neoliberalism [16], scarcity and abundance [17,18], community [19], and citizenship [20]. Relatedly, authors have built on Foucauldian ideas to reveal how authorities target certain populations to restrict, malign or reform the water practices available to them through such things as technologies and governance measures [21,22], colonial infrastructure configurations [23], discourses of culture and identity [24], ideas of illegality and informality [25,26], and performance indicators [27].

For Lefèbvre, society and the everyday are mutually constitutive: they can only be understood in interaction, separately they make little sense. The everyday is thus distinct from praxis, it is not mere action or reaction: it "encompasses base and superstructure and the interactions between them" [3] (p. 50). It is a zone of intersection between the dominated and non-dominated sectors of life. In this way, while the everyday is targeted for manipulation and management, it has its own rhythms and thus constitutes a site of continuity, transformation and feedback. To grasp these dynamics without succumbing to grand theory or empiricism, Lefebvre [3] (p. 191) advocates that: "we take the phenomenon as is: an ensemble 
of constellations, thus of observed differences, linking them without ontological presumption. The total phenomenon can thus vary in relation to knowledge and practice, without maintaining the unity of an 'essence' or ( . . ) being lost in fragments ( ... ) via dialectic reasoning that seeks perpetually to grasp a whole from the differences and conflicts of its parts". Thus, while class interests work on the everyday through culture, work, technology, propaganda, the everyday acts as both "the residuum ( ... ) and the product of society in general, it is the point of delicate balance and that where imbalance threatens" [28] (p. 32).

In these dialectics of the everyday, the interplay of cyclical and linear time and of needs-desires are everywhere producing interference and change. While cyclical time refers to the long intervals of biology, the family and the cosmos, linear time is formed of the "livelier, alternating" rhythms of knowledge, reason, technology and work [29] (p. 40). These interacting rhythms are circular and repetitive, they change significantly over time and are lived individually but also in social bodies: groups, crowds, classes. Together they constitute social or everyday time, which interacts with social space, consisting of the environment of the group and of the individual within that group. The extent of the horizons of this space-its tissue of networks and pathways-differ from group to group, their situation and their distinct activities [3] (p. 233). In this way actions do not occur in space, they produce space [30] (p. 116). Likewise, for Bourdieu, any adequate analysis of practice must consider the spatial and temporal context, treating temporality as one of its central features [31] (p. 69). In Hydraulic City, Anand [32] for example reflects on "water time", which involves the rhythms of bodily needs related not only to water but to eating, sleeping, and ritual. This time intersects with that of water availability to produce a set of daily rhythms that produce the space of the home and of the local community. Water time is generally a time lived by women in ways that differ depending on class and the horizons of their social space.

Due to disjunctures between social time and the "time of accumulation", and between social space and the spaces of "cumulative processes" [28] (p. 61), society seeks to programme the everyday by acting upon needs-desires. For Lefebvre [3] (p. 193), "man only becomes human through human needs, that are artificial with respect to nature" and individualized into desires "through controls and permissions, inhibition and possibility", generating "a dialectic movement ( ... ) which fills the everyday". The needs-desires dialectic is distorted through the pressures of capitalist consumption, shifting norms, state bureaucracy and technology, filling the everyday with terror (e.g., about our appearance and our behaviours), creating a "space-time of voluntary programmed self-regulation" from which women suffer most [28] (p. 72). We "clip our own wings" in response to the "cringes that limit our field of action" [5] (p. 14). Still, the everyday remains open "because 'something' irreducible intervenes" this could be desire, reason "or even the City" [28] (p. 73).

Up to this point, Lefebvre's more structuralist orientation is discernible only in his analysis of how society acts upon needs-desires, which he limits to the "organized society of controlled consumption" in his later work. This evolves from and sits in some contradiction with his earlier writings. To better contextualize this tread of his thinking, we explore it through his argument with the pragmatists in the section below. Bourdieu, by contrast, while proposing a model for analysing the relationship between structure and practice, managed to keep his framework untethered from particular phenomena and thus particular historical-geographical contexts.

For Bourdieu, social life is a game that is essentially practical. Practice is not wholly consciously organized and orchestrated: "nothing is random or purely accidental but, as one thing follows on from another, practice happens" [31] (p. 70). This is contextual, understanding practice means "to do more than simply take what people do in their daily lives for granted, and to do so without losing sight of the wider patterns of social life" [31] (p. 68). As for Lefebvre, practice cannot be understood outside of time and space. These positions are summed up in Bourdieu's notion of "practical sense or practical logic", which means a "feel for the game (...) a mastery acquired by experience of the game, and one which works outside conscious control and discourse" [33] (p. 10). This has two facets. The first is "doxic experience": the necessity imminent in the social world, whereby the position one 
occupies in social space renders one largely incapable of perceiving the arbitrariness of social reality as anything other than "the way things are" [31] (p. 70). The second refers to the characteristic fluidity and indeterminacy of social life, which (in all of its complexity and variety) is not accomplished on the basis of rules, recipes, or normative models. Instead, it is the "art" of necessary improvisation which defines excellence [31] (p. 71). This involves "strategizing" to meet goals and interests in ways that locate practice in people's own experience of reality [31]. Through the concept of strategizing, Bourdieu presents practice as the product of processes which are neither wholly conscious nor wholly unconscious, rooted in an ongoing process of learning which begins in childhood and through which actors know-without knowing—the right thing to do [31] (p. 72).

On this particular point, we can observe the resemblances between Bourdieu and pragmatic thought, especially phronesis, as well as with the epistemological position of Rivera-Cusicanqui. For each of them, practice is learned through practice. In this regard, Bourdieu also offers a framework for the analysis of practices in context based on his concepts of capital, habitus and field. The field refers to the social area in which events occur, it is bounded and offers "opportunities and constraints". Within the field, capital (how power and prestige are understood) and habitus (practices, embodied, but learned for and within the field) interact, shifting the nature of the field and how the actors relate within it [33]. Using this framework, Rebecca Lave [34] has explored how certain types of water governing "habitus" come to dominate over others. In her work, the "field" is that of stream restoration in the United States. She documents how amateur stream restoration practices developed by Dave Rosgen came to dominate over those of fundamental and applied science due to changes in the "capital" of stream restoration knowledge under the neoliberalization of funding models, which favour simpler, readily applicable and easily replicable techniques. Bourdieu's capital-field-habitus framework has also been applied to understand shifting access to land and water in Uzbekistan [35], water related health risks and vulnerability in Chennai, India [36] and exposure to wastewater in Delhi's "slum" neighbourhoods [37].

Although a "framework", Bourdieu's approach remains quite open. For Bourdieu "the relation between the social agent and the world is not that between a subject (or a consciousness) and an object, but a relation of "ontological complicity" or "mutual possession" [38] (p. 20). Habitus thus refers to a deep structure or transposable dispositions generative of all thought and behaviour, one that orients practice without producing it [39]. Despite this principle of regulated improvisations, he recognizes the socialized body, not as an object, but as a repository of a generative, creative capacity to understand, endowed with a structuring potency [38] (p. 20). Similarly, through the concept of dressage, Lefebvre "scrambles the distinction between forced adaptation, pleasurable variation, and threatening dissolution of life-confirming norms", the everyday emerges as "an intersecting space where many forces and histories circulate and become 'ready to hand'" enabling the invention "of new rhythms for living, rhythms that could, at any time, congeal into norms, forms, and institutions" [40] (p. 9).

This perspective, whereby practices possess a certain autonomy and produce feedback effects on society, is also shared by de Certeau who takes it further, concentrating his work on the ways in which practices transgress the pressures of broader society. He is interested in following the "multiform, resistance, tricky and stubborn procedures that elude discipline without being outside the field in which they are exercised" [41] (p. 96). Such practices structure the determining conditions of social life in contradictory ways that operate between the collective modes of administration and the individual modes of re-appropriation. They can refer to linguistic enunciations or be extended to cover non-linguistic activities such as walking or cooking. The act of "walking", for example, is to the urban system what the speech act is to language. To get at these practices, de Certeau insists on the importance of not only what is done, but of how it is done, which requires close anthropological attention, being attentive to the detailed, idiosyncratic "murmurings of the everyday" [41] (p. 70).

In this way, de Certeau's theory of practice presupposes a subject that, while in dialogue with both the sociologism of Bourdieu and the discipline of Foucault, is conceptually distinct from 
both. de Certeau is concerned with the practices of knowledge-doing as opposed to Foucault's knowledge-power. This means "revealing and describing the ways in which populations resist the encroachment of disciplinary mechanisms, the practices of evasive conformity by which they camouflage their "miniscule" disruptions of an order they cannot openly contest" [42] (p. 55). Thus, de Certeau's task is the opposite of Foucault's. Instead of exposing the mechanisms of a disciplinary order, he pays attention to the clandestine practices that at their ideal constitute a "network of an anti-discipline" [41] (pp. xiv - xv). While the urban system seeks to suppress and control these "microbe-like, singular and plural practices" they live on "reinforceing themselves in a proliferating illegitimacy, developing and insinuating themselves into the networks of surveillance ... constituting everyday regulations and surreptitious creativities" [41] (p. 96).

In contrast to Bourdieu, de Certeau argues that practices are better interpreted as "tactics" than "strategy". Where strategy refers to the large-scale manoeuvring of a regular military unit from places of fortification, tactics refer to the skirmishes of a guerrilla force from places of momentary occupation. The possibility of indeterminacy offers the best chance of popular resistance to technocratic rationality, not a resistance of one force or one reason over another, but the evasion of force, of reason, and of capture. Thus, practice involves transgression, whose ambiguity lies in its total dependence upon the law that is to be transgressed, it is "escape without leaving" [41]. Such transgressive practices are everywhere in the literature on governing water, including work on unregulated connections [43], meter tampering [44], selective application of fines [45], and efforts to help marginalized users defend their rights against water companies [46]. Still, such practices are often infused with precarity [47] even-if not especially [48]-where they are unofficially appropriated by the state [49].

\section{Anti-Theory: Building from Practices}

The American pragmatists go further in giving priority to practice and in eschewing general laws. William James, one of pragmatism's early figures, was convinced that philosophy should be concerned with action as opposed to abstraction, with what is, as opposed to what ought. This does not mean that action occurs in a vacuum, but that it cannot be reduced to general laws and that it is constructed circumstantially, in context. It must be seen as alive, dynamic, learned and retooled [50]. For the pragmatists, things hold truth because they "work" in a particular time and place and for particular ends-not due to foundational laws that hold true in every case. As such, when a "truth" ceases to work as circumstances change, new ways of thinking and doing are adapted. In this way, knowledge is developed through practice, it is "always fallible and always provisional" [51] (p. 3). This is not about habit but about embodied consciousness, a form of knowledge that transcends the mind-body dualism that has dominated western philosophy [52]. This resonates with phronesis whereby true expertise is developed through experience rather than following a prescribed set of steps, rules or theories. Over time and through practice, knowledge becomes embodied and reactive and thus adaptable to new and more complex situations in which the rulebook cannot be readily applied [7].

This emphasis on the provisional nature of relations in producing the everyday has implications for perspectives on power and dominance. For the pragmatists, power emanates from relations as opposed to inherent properties. In this sense, outcomes of the exercise of power cannot be predetermined from what seems powerful a priori. Rather, it must be understood both contextually and relationally, examining how "contexts" interact with and modify the possible $[53,54]$. In contrast to Foucault, for the pragmatists power is not everywhere, it is specific and relational and felt in the everyday [55]. To this extent we can say that they understand power as decentred and provisional. This view of power focussed on relations as opposed to attributes can help to examine infrastructures more critically, adding nuance to ideas of obduracy, stability and dominance prominent in work on Large Technical Systems (e.g., [56,57]). By way of example, capital flight and austerity can turn large infrastructures into sites of abandonment and decay [58], where workers are forced to turn to outdated and degraded technologies to maintain activities like navigation [59]. A decentred perspective can likewise shift the focus from piped water to the multiple urban waters that are not contained by urban infrastructure and the diversity of practices they imply [47]. 
Pragmatism has had its share of critics. Lefebvre [3] (pp. 235-236) charged it with individualism, an overvaluation of "success", and evacuating "the drama of individual life and social life, the depth, the problems". Still, pragmatic thought—much like Lefebvre's own-seeks a way of thinking through what people do in the everyday that is both tied to structure and separate from it. It is not about "success", but about "making things work", the possibility of which is often bound by circumstance [60]. Rather, the two diverge in their view of how society and practices form one another. For Lefebvre, the influence of capital and the state are central to how the everyday is structured by society through what he calls the "organized society of controlled consumption" [28]. The pragmatists, who are more suspicious of grand theory, refrain from specifying what the dominant social forces acting upon practical action might be. They also take a more modest view of the impacts of practices on wider society, referring not to "society" but to something more equivalent to context. For Dewey [60] (p. 39), "every genuine experience has an active side which changes in some degree the objective conditions under which experiences are had". Both are relevant for thinking about water. While Lefebvre's approach could be helpful in relation to bottled water consumption in wealthy countries where potable water is readily accessible, marketing plays a strong role in developing the associated "need-desire", and the emerging habit of bottled water consumption affects wider society through new industries, regulations and waste [61], a pragmatic approach may be useful in thinking about the increasing importance of different forms of packaged water that are spreading across cities where potable water supply is limited and state services may be viewed with greater suspicion $[62,63]$.

Nigel Thrift's non-representational theory-coming many decades later-shares with pragmatism a rejection of any theoretical starting point, emphasising the need to start from practices. For Thrift [5] work that begins from a theoretical position risks missing how things actually play out. Beginning from practices not only avoids the contemporary propensity for "over theorization", it is key to advancing, destabilizing and improving theory. Non-representational theory then refers to an approach that seeks not to represent but first to observe and understand, as prior to theorization. It is by definition experimental. Yet the individual is not the object of focus, the approach should be "anti-biographical and pre-individual" avoiding "oneness" or singularity and taking a "faint" view of human agency [5] (p. 3, p. 7, p. 14). Going back to the pragmatists, all practices are deeply social and socialized-" there is no attitude which is exclusively private in scope, none which does not need to be socially valued or judged" and "habitual dispositions" are evaluated in their "tendency ... to secure (or hinder) values which are sociably shared or sharable" [64] (p. 383).

Some aspects of Thrift's thinking that are more particular to him (if not always in substance, then in emphasis) include his focus on the role of objects and his thinking on the afterlives of practices. First, drawing on Schatzki [65], whose work focuses on the role of the material in the construction of the social, he summarizes practices as "productive concatenations that have been constructed out of all manner of resources and which provide the basic intelligibility of the world" [5] (p. 8). These "all manner of resources" include the biological and the body, and especially things, which should be given equal weight to practices as these require objects "against which to react and from which to learn" [5] (p. 20). The body and its organs develop in relation to things, having evolved "in part in response to the requirements of tools which have subsequently produced changes in the brain", making the human body a "tool-being" [5] (p. 10). Following Latour [66], these interactions are multiple and not predetermined. Second, he not only sees practices as evolving in relation to new circumstances—through pragmatic "extension"-but practices themselves "leave abandoned wreckage behind" as practices change. These do not simply disappear but "take on new life, generating new hybrids" [5] (p. 10). Most importantly, however, they leave behind their artefacts, which will continue to interact-reverberate even - with a variety of other somethings and practices in the everyday. Along similar but different lines, Dewey sees experiences as extending into time in ways that cannot be known a priori: "no experience lives and dies to itself. Wholly independent of desire or intent, every experience lives on in further experiences" [60] (p. 28).

Thinking about the role of objects and the afterlives of practices within contexts of economic inequality and mistrust of the state, authors have documented the diverse relations between people 
and the technologies of water access. Users, for example, resist the roles inscribed in water meters, undermining them by formally challenging utility bills and through direct tampering to distort consumption readings $[46,67]$. In another way, retaining long established practices like rainwater collection in coexistence with piped water supply, when it is extended to previously underserved neighbourhoods, serves to create spaces of independence from state control in a form of subversive "tool-power" [68], which are simultaneously essential for the functioning of the improved system and its material relations with users [69].

\section{Problematic Situations: From Crisis to Care}

Contemporary relationships to water-be they urban or rural, north or south-are fraught with challenges and limited capacities to achieve water justice or to advance water rights. Many factors may intervene, from the ordinary to the extraordinary. And, what was once extraordinary, has a way of becoming an ordinary element of the everyday, even in its production of precarity [40]. Today, around the world, providing, accessing and working with water are fraught with complication, contradiction, and often hazard. Water is contested between competing uses, subject to power relations, a carrier of pollutants and a vector for diseases. It can be scarce, especially in potable form, and arrive in devastating quantities through floods and arroyos, carrying debris and waste. It is subject to neoliberal and technical control, directing it to certain uses and limiting others, converting it into hydroelectricity, unaffordable utility bills and debt. Its infrastructures are unequal and subject to decay. How do people manage in these circumstances that are at once extraordinary and common? What can the literature on practices tell us? How can it help us to build better-if incongruent- explanations?

One thing that authors concerned with practices agree on is that such circumstances are exceedingly common and that most people's lives are restricted by a range of factors that make the everyday difficult and precarious. For Thrift [5] (p. 20), most people actually have little room for choosing in their daily lives; "currently, many people are forced to live their lives in cramped worlds which offer them little or no imaginative relief because of the crushing weight of economic circumstance, the narrow margins of what they are allowed to think by what they have been taught and what lies bleeding around them and the consequently almost routine harrowing of their confidence that the world can ever be for them". As Roca-Servat $[70,71]$ shows, subaltern communities who live without water supply in the city of Arequipa (Peru) can never really be free in their relationships with the state; it is a constantly negotiated relationship in which sometimes they are able to challenge and sometimes they must go along with hegemonic power. For Lefebvre [3], the oppression of the everyday-the way it confines possibility-stems from social pressures that confine particular people to a set of norms, strictures, tasks, rhythms and expectations, "the misery of everyday life, its tedious tasks, humiliations reflected in the lives of the working classes and especially of women, upon whom the conditions of everyday life bear heaviest" [28] (p. 35). In keeping with the extensive work on the gendered nature of water and the importance of intersectionality therein (e.g., [72-74]), the gendered tyranny of the everyday is subject to factors like class and "group", and constitutes "the essence of the everyday" [3] (p. 17).

Berlant and Kleinman take these perspectives further, focussing on periods of crisis and trauma. For these authors crisis is a normal part of the everyday, not an aberration. In denying this reality, contemporary society exerts not simply a diffuse power following Foucault or a mix of bureaucratic control and consumer desire following Lefebvre, but also a "fantasy" of the good life. By creating the illusion that our lives can be "controlled and orchestrated", that they are stable and free of risk or challenge [75] (p. 12), our social worlds encourage "people [to] hoard idealizing theories ( ... ) about how they and the world 'add up to something'" [40] (p. 2). This vision masks the constancy of life's fragility. This fragility, or what the pragmatist William James called "genuine reality" [75], can intervene at any time in the form of illness, debt, family breakup, death, unemployment, violence, loss of property or place in society and so on.

In Cruel Optimism, Berlant focusses on practices in the context of precarity, of dreams that cannot be realized. She considers how the everyday is infused with crisis(the "crisis ordinary"), whereby one 
must struggle to retain normality, integrating adaptations to crisis into habit [40] (p. 63). In this way, she reverses the perspectives on the everyday developed by de Certeau [76] and Lefebvre [29]: "Instead of the vision of the everyday organized by capitalism ( . . ) I am interested in the overwhelming ordinary that is disorganized by it, and by many other forces besides" [40] (p. 8). Here, crisis is "embedded in the ordinary that unfolds in stories about navigating what's overwhelming". How people adjust is neither uniform nor individual but is "powerfully related to the expectations of the world they had to reconfigure" [40] (p. 20). Thus, although these relationships are indeterminate, how the crisis-ordinary is lived and managed depends on the individual as well as the individual within their social world, their expectations and their confidence stemming from their relative entitlements.

In many ways, Berlant's work echoes pragmatic perspectives in that it is not about shock or upheaval but about integrating the regularity of crisis and trauma into the everydayness of getting by. During times of crisis, the everyday must be maintained else "all energy would be sucked into the decisionism of a life lived minute to minute" [40] (p. 63). Here she draws on Lefebvre's [29] Rhythmanalysis, whereby habituated responses are "stretched" avoiding ruptures and enabling adjustment. Here, even a "visceral response is a trained thing": "intuition is where affect meets history, in all of its chaos, normative ideology, and embodied practice of discipline and invention", where "adjudication, adaptation and improvisation" are always ongoing [40] (p. 52, p. 54). In the words of Thrift [5] (p. 21): "what was missing from too many accounts of practices was a sense of mutability, of the moments of inspired improvisation, conflicting but still fertile mimesis, rivalrous desires, creative forms of symbiosis, and simple transcription errors which make each moment a new starting point".

Such circumstances also imply ethical dilemmas, which put ethics squarely within the dialectics of the everyday and the social worlds in which people might act as opposed to a kind of reasoning that is universal, rational and independent of context. To think through these issues, Collier and Lakoff [77] (p. 59) develop the "concept of the regime of living as a tool for mapping specific sites of ethical problematization", where a regime of living refers to "a tentative and situated configuration of normative, technical, and political elements that are brought into alignment in situations that present ethical problems-that is, situations in which the question of how to live is at stake (...) requiring a situated form of moral reasoning". Contemporary "problems of living" are composed of a range of influences and factors, including the technical and the biopolitical, which "stand in flexible, provisional, and tense interrelationship". For these authors, understanding how regimes of living evolve requires a perspective that echoes that of the pragmatists. They involve "a certain capacity for extension or abstraction" that can be adopted by people — either individually or collectively-in situations of uncertainty "characterized by a perceived gap between the real and the ideal, that are in search of norms and forms to guide action". These are constantly in the making, making ethics an anthropological as opposed to an intellectual problem whereby "the nature and practice of human life and the telos of living are constituted and reconstituted" as contexts and circumstances shift and change [77] (p. 32, p. 36).

For Berlant, the crisis ordinary is not just about the denial of the precarity that is ever lurking at the margins, the "extraordinary always turns out to be an amplification of something in the works, a labile boundary at best, not a slammed-door departure" [40] (p. 8). Lefebvre [28] (p. 9) also recognizes this continuity but sees it (at least in the extreme case of war) as leading to rupture rather than adaptation. For him, such situations make the everyday impossible, giving way to the realization that the logic and order of the past "were only paving the way to tragedy". Indeed, it is when people can no longer lead their everyday lives that a "revolution takes place." To avoid this, the everyday must be "constantly re-established" [28] (p. 32). In the "guerra del agua" that erupted in Cochabamba (Bolivia) in the late 1990s, for example, the "revolution" that resulted in the expulsion of the private water company was a direct reaction to efforts to prohibit long-established practices such as rainwater collection [78-80].

Engagement with the feminist politics of care offers an important response to evolving precarity. Developed by feminist scholars concerned with women's labour, the politics of care argues that the intimate and interpersonal are ultimately embedded in wider politics [81]. Subsequent work sought to 
encompass activities beyond the intimate sphere, asserting that acts of thoughtfulness, responsibility, education and compassion are elements of a good society and imply a radical transformation of the nature and the boundaries of the moral [82] (p. 28). For Laugier [83], care should be understood as a politics of the ordinary in that it is influenced by context as well as the particular and the material. Thus, while neoliberalism constrains the ability of people (particularly women) to engage in caring practices, it also makes these practices more necessary for both communities and the state. Through ethnographic work in Santiago de Chile, Han [84] describes how, in a context of precarity and market reform, care unfolds through concrete neighbourhood networks. In this way, the neoliberal reworking of state-social relations has rendered care increasingly important in meeting individual, family and community needs [85].

These acts go beyond pockets of coping, shifts in caring strategies may respond to changes in public policy, but are themselves potentially politically transformative [86,87]. To capitalize on this potential, Lawson [88] (p. 221) calls for a radical geography that moves from research and theorization to the transformation of "uncaring relations between people and ecologies, raising crucial questions of practice". This ethics of care requires the crafting of context-specific policies, of "practically adequate reforms, grounded in actually existing conditions producing exclusion and privilege" [88] (p. 221). The evolution of water supply regulation in Colombia offers some inspiration with respect to ethical policy engagement. Since the mid-20th century, state policies of regulated solidary have required the cross-subsidization of utility services (and their extension) whereby those with greater means subsidize the access of lower-income sectors $[89,90]$. This is useful in thinking through an ethics of care that engages the state, contributing to the institutionalization care.

The politics of care extend to caring for the "things" upon which others depend. This involves a "persistent tinkering in a world full of complex ambivalence and shifting tensions" [91] (p. 14). This is necessary given the material fragility of things and extends to infrastructural maintenance work as a practice of care $[92,93]$. Reminiscent of Thrift and the pragmatists, in a world where infrastructure is vulnerable, maintenance workers combine standardized procedures and improvisation, whereby the physical engagement with things generates embodied knowledge and practice that constitute a form of care [94]. This "persistent tinkering" and "taking care of things" is visible in everyday Barranquilla (Colombia). From 1994 to 2004, the city's low-income neighbourhoods received nearly 120,000 internally displaced people. Given the fragile state of local infrastructure, residents in these neighbourhoods organized and performed regular maintenance and repair, with men from the community, who became known as marañeros (entanglers), building and repairing electricity networks and women organizing cleaning crews that became known as escobitas (lady brooms). Such organized acts of care make life in the city possible but are simultaneously racialized and gendered in ways that put bodies at risk [95].

Latin American feminist scholars also emphasize the importance of care. Their work traces the unequal power relations that make invisible the everyday caring practices of people across the continent, including the work of Mayan women in caring for their communal lands and aqueducts in Guatemala [96], of people (particularly women) in developing a communitarian capital through popular pragmatics and baroque economics in places like the La Salada market in Buenos Aires (Argentina) [97], and of women throughout Mexico in rebuilding communities through practices of caring for communal resources like water [98]. For these authors, women are generally at the centre of the everyday politics of caring through the work of reproducing life in everyday, from practices of decision-making to cleaning [96-99].

\section{Silvia Rivera-Cusicanqui: Decolonizing Practices from Latin America}

Concerned with intersections of class, ethnic and gendered identities in the production of inequality, Aymara scholar Silvia Rivera-Cusicanqui of Bolivia offers a method for thinking about practices and the everyday, through the metaphor of ch'ixi. Ch'ixi is a decolonizing practice, as it serves to embrace the permanent struggle in Latin American subjectivity, where life is characterized by multiple differences, differences that are the legacy of colonialism [100]. Ch'ixi engages these differences in processes of 
mestizaje, whereby contrasting black and white threads are woven together but remain separate and distinct while appearing as a unified grey from certain vantage points.

Rivera-Cusicanqui argues that we can subvert this legacy by observing from uncertainty in order to see possibilities that are hidden by established ways of thinking and observing: "there is no support for a discourse or theory of decolonization without the existence of decolonizing practices that give them life and meaning" [101,102]. Listening, being silent and doing are fundamental parts of this project. Through attentive listening we can recognize the knowledge embedded in experience. Listening implies reading between the lines and unearthing hidden truths to reinterpret things and reinvent ourselves [103]. Silence is important because it allows us to breathe and reflect [104]. Actions (or doings) exceed description and must be practiced to be understood, "by cooking, sewing or making protest signs" [6,104].

Decolonizing practices—or ch'ixi—can only be learned through practice. Academic or institutional discourses are insufficient, as words tend to elude practices. For Rivera-Cusicanqui, knowledge entails doings and daily commitments that are mistrustful of words, academic jargon, and generalized theories written from a desk and disconnected from experiences of everyday injustices $[6,105]$. In the spirit of ch'ixi, Rivera-Cusicanqui communicates her work orally, through lectures, interviews, and conversations as opposed to the standard channels of academic publishing. Here, orality prevents the stabilization of language and opens possibilities for more nuanced flows of thought [103]. Thus, her own work avoids finished theory held together by fashionable concepts. Instead, it involves a bodily disposition, that is on the move (trajinar), walking and meeting. It implies "a way of thinking by modifications, in which thoughts are constantly amended, reworked and completed through journeys, political alliances, by walking with others, separating and then coming back together" [106].

Ch'ixi responds to Aymara understandings aiming to communicate the complex Andean cultural framework in which a thing is and is not at the same time, referred to as the "logic of the third included" [1]. It implies the contentious dynamics that bring together western and indigenous understandings without reconciling them. Ch'ixi allows us to think about the coexistence of heterogeneous elements that do not aspire to merge or produce something new, which would surpass and encompass them [1] (p. 7). Neither synthesis nor fusion, it approaches what Bolivian author René Zavaleta calls variegated society - sociedad abigarrada, emphasizing the parallel coexistence of multiple cultural differences that do not merge, but antagonize and complement one another. Thus, one must be open to contentious oppositions, embracing interpellations, distress and questions. We should not be afraid of inconsistency because "the greatest inconsistency lies in knowing without living" [6]. To ignore contradiction is to overlook the emancipatory potential of the coexistence of opposites, ascribing ascendency to one of them. It is only when opposites are maintained that decolonizing gestures are possible. In their purity and strength, we can discover a decolonizing energy that allows the shaking off of inherited structures [104] (p. 224). In terms of governing water, this means taking different natures, ontologies and ways of governing of water seriously, without seeking to reconcile differences or prioritize a given worldview [107].

For this we must shed the economic strategies and the material mechanisms that operate behind discourses: replacing a 'geopolitics of knowledge' with a "political economy" of knowledge. This calls for suspicion in the face of discourses like the human right to water that circulate in international and national networks. Such discourses come from places of power like the state and the law, and are constructed from places of arrogance and securitization, silencing other voices, meanings and practices [106]. For Rivera-Cusicanqui the conditioned and reluctant recognition of indigenous cultural and territorial rights in Latin America has enabled the continuity of elite monopoly power [102] (pp. 58-59). As a result, environmental rights like the human right to water are articulated as assets or rights of an elite or as consumption goods [102] (p. 60). Similarly, Zwarteveen et al., [108] (p. 3) take issue with the term governance as a tool to "normatively prescribe or help design particular institutional, organizational, and financial arrangements for making water decisions and regulating water". Often without scientific foundation, the ensuing good governance prescriptions rest on 
"ideologically informed speculations about what society or development should be, rather than from in-depth empirical understanding of how water governance actually occurs".

For water in Latin America, this means being attentive to the gaps between the worlds in which global discourses are fabricated, and the worlds in which it they are meant to take effect. The latter is a world of contradictions. A world that is a product of the legacies and contemporary expressions of colonialism, where the force of experiences positioning themselves as "correct" clash with the strength of local traditions attached to other values and meanings. This clash is characterized by a lack of respect toward difference, emphasized in the imposition of standardized measures. In response, critical work has emphasized water's many natures rejecting stabilized approaches that limit water to a status of "natural resource" [109]. These many natures include diverse meanings of drinking water quality and potabilization [110,111].

Instead of focusing on the limits to change in the face of neoliberal politics, Rivera-Cusicanqui and other Latin-American scholars like Gutierrez-Aguilar concentrate on the possibilities of hope and transformation. These can be found in micro-political practices, such as those assembled from everyday popular doings, as well as in moments of crisis. They can also be created through ch'ixi. Not unlike de Certeau's thinking, even clandestine, everyday micro-political doings wield power, a power of the community against the state [112]. In Cochabamba (Bolivia), communities organized and sustained daily roadblocks, marches, and occupations of the city through the Coordinadora del Agua (Water Coordination Committee) and compelled the state to cancel the privatization of the city's water utility [113]. In terms of crisis, while Berlant emphasizes the crisis ordinary, Rivera-Cusicanqui insists on the productivity of crises as moments when meanings, experiences, and memories are trembling and unstable and ripe for transformation. Times of crisis can create spaces of possibility to rethink and reorganize who we are and how we live [103,106]. Similarly, Solway [114] finds that drought can act as a "revelatory crisis", where asymmetric socio-economic power relations are exposed and questioned. Like Rivera-Cusicanqui, Solway thinks of crisis as a moment of potential social change that opens space for contestation but can likewise conceal the deeper roots of crisis in inequality.

The emancipatory possibility lies in the ability to recover creativity in the episteme of decolonizing forms. This can be achieved by following three principles. The first is a plurality of activities, avoiding the tediousness of mechanized industrial work in favour of collective work in all its multiplicity and creative potential [100]. The second calls for the weaving of words and acts, limiting the gap between them, which is widened in colonial society. It invites us to weave antagonistic forces and give them a purpose, to create forms of sociability that imply the coexistence of difference, and to generate spaces of exchange and friction transforming contentiousness into a zone of interweaving [106]. The third insists that none of these efforts are ever only "ours". They exist only if they "are contaminated, dirty, stained and partially inhabited by others" [104] (p. 225). This requires a self-conscious poiesis capable of creating conditions of full respect for the individual without diminishing the strength of the collective.

In Bolivia and Colombia, the collective everyday efforts of those engaged in community-run water systems-acueductos comunitarios-involve a plurality of activities at different scales that enable communities to safeguard space for their work as well as the long-term integration of their labour and ideas into municipal and national water plans $[115,116]$. Similarly, communities in Colombia have instigated processes of environmental democratization, defying big mining conglomerates and state repression, through constitutional lobbying and activism involving a diversity of creative alliances and mechanisms of democratic participation [117]. These are just some examples of how everyday practices are nurturing new forms of organization and new languages for governing water and the environment [104] (p. 227).

\section{Conclusions}

Inspired by the work of Silvia Rivera-Cusicanqui, in this article we sought to weave ideas about practices and the everyday in an open and contradictory way. We offered a fabric in the making, for approaching practices related to the forms of governing and lending meaning to water. Instead of 
trying to create a uniform or harmonious theoretical framework, we recognize difference and leave it unresolved. We began this tapestry with the work by Foucault on the translation of specific discourses into practice, reproducing power relations and inequalities. We wove Foucault's concern with the workings of power and their effects on lived experience, with the ideas by Lefrevre, Bourdieau, and de Certeau, which address practices and the everyday as their primary object of focus. Here, Lefrevre's thoughts on voluntary self-regulation and the irreducibility of the everyday, stand side by side with Bourdieu's concerns on the theorization of the relationship between social strictures and practice and with de Certeau's focus on the ways in which practices transgress the pressures of broader society.

Adding scholars from another continent to the weave, we engaged with the work of pragmatists on how the everyday is alive and dynamic and cannot be reduced to general laws; it is constructed circumstantially and in context. Here, knowledge, which is developed through practice is "always provisional". These arguments are braided with Thrift's focus on the role of objects and on the afterlives of practices and the work of scholars like Lauren Berlant on crisis as a normal part of the everyday. Ideas around care complement this part of the tapestry: in contexts of everyday precarity, care encompasses a number of activities related to responsibility, education and compassion.

Echoing both pragmatic and non-representational perspectives, we argue that knowledge must begin from practices, from the observation of the everyday and not from any pre-established theoretical perspective. In this spirit, our engagement with the scholarship on practices and the everyday does not seek to resolve the tensions between them, but to put them out there respecting Rivera-Cusicanqui's call to observe and listen, embracing uncertainty in order to distance oneself from a dichotomous vision of the world since differences, present in the fragments, can consist of radical opposites. This contravenes the generalized conviction, naturalized by standardized proposals in water management, whereby the contentious coexistence of difference is negated, supressing possibilities for chi'xi consciousness. The invitation is thus to remain attentive in order to perceive differences where everything seems uniform; to celebrate the stains, the contradictions, the unexpected shortfalls and the creativity.

Author Contributions: Conceptualization, K.F., D.R.-S., T.A.-G., and M.B.-M.; methodology, D.R.-S. and M.B.-M.; formal analysis, K.F., D.R.-S., and T.A.-G.; writing-original draft preparation, K.F., D.R.-S. and T.A.-G.; writing-review and editing, K.F., T.A.-G., and D.R.-S.; funding acquisition, K.F. and D.R.-S.

Funding: This work is supported by the Social Sciences and Humanities Research Council of Canada (SSHRC) through grant \# 435-2016-0356 "Historicizing southern urbanisms: Water supply development in Colombia 1910 2014", and by the Center for Research Development and Innovation of the Universidad Pontificia Bolivariana in Medellín, Colombia CIDI UPB INNOVA 2018 under grant number 101C-05/18-12 and the project entitled "Historizando Urbanismos en el Sur Global: el derecho al agua en Colombia y su legado contemporáneo a partir de los casos de Cali, Medellín y Bogotá. PARTE 2".

Acknowledgments: Many thanks to Leonor Mesa for her help transcribing video footage of Silvia Rivera Cusicanqui's conferences.

Conflicts of Interest: There are no conflicts of interest to be declared.

\section{References}

1. Rivera-Cusicanqui, S. Ch'ixinakax Utxiwa. Una Reflexión Sobre Prácticas y Discursos Descolonizadores; Tinta Limón Ediciones: Buenos Aires, Argentina, 2010.

2. Furlong, K.; Carré, M.-N.; Guerrero, T.A. Urban service provision: Insights from pragmatism and ethics. Environ. Plan. A Econ. Space 2017, 49, 2800-2812. [CrossRef]

3. Lefebvre, H. Critique de la vie Quotidienne II: Fondements d'une Sociologie de la quotidienneté; L'Arche Éditeur: Paris, France, 1961.

4. Barnes, T.J. American pragmatism: Towards a geographical introduction. Geoforum 2008, 39, $1542-1554$. [CrossRef]

5. Thrift, N. Non-representational Theory: Space|Politics|Affect; Routledge: New York, NY, USA; London, UK, 2008.

6. Rivera-Cusicanqui, S. Video: Prácticas y Discursos Descolonizadores; Cristian Rasgado: Oaxaca, Mexico, 2015.

7. Flyvbjerg, B. Making Social Science Matter: Why Social Inquiry Fails and How It Can Succeed Again; Oxford; Cambridge University Press: New York, NY, USA; London, UK, 2001. 
8. Hall, S. Foucault: Power, knowledge and discourse. In Discourse Theory and Practice: A Reader; Wetherell, M., Taylor, S., Yates, S., Eds.; Sage in association with the Open University: London, UK; Thousand Oaks, CA, USA, 2001; pp. 72-80.

9. Foucault, M. Power/Knowledge: Selected Interviews and Other Writings 1972-1977; Gordon, C., Ed.; Pantheon Books: New York, NY, USA, 1980.

10. Foucault, M. Histoire de la Sexualité; Éditions Gallimard: Paris, France, 1976.

11. Escobar, A. Encountering Development: The Making and Unmaking of the Third World. Popul. Dev. Rev. 1995, 21, 430.

12. Swanson, M.W. The Sanitation Syndrome: Bubonic Plague and Urban Native Policy in the Cape Colony, 1900-1909. J. Afr. Hist. 1977, 18, 387-410. [CrossRef] [PubMed]

13. Gandy, M. Landscapes of Disaster: Water, Modernity, and Urban Fragmentation in Mumbai. Environ. Plan. A Econ. Space 2008, 40, 108-130. [CrossRef]

14. Gandy, M. The Fabric of Space: Water, Modernity, and the Urban Imagination; The MIT Press: Cambridge, UK, 2014.

15. Bakker, K. Constructing 'Public' Water: The World Bank, Urban Water Supply, and the Biopolitics of Development. Environ. Plan. D Soc. Space 2013, 31, 280-300. [CrossRef]

16. Ekers, M.; Loftus, A. The Power of Water: Developing Dialogues between Foucault and Gramsci. Environ. Plan. D Soc. Space 2008, 26, 698-718. [CrossRef]

17. Alatout, S. 'States' of Scarcity: Water, Space, and Identity Politics in Israel, 1948-1959. Environ. Plan. D Soc. Space 2008, 26, 959-982. [CrossRef]

18. Alatout, S. Bringing abundance into environmental politics: Constructing a Zionist network of water abundance, immigration, and colonization. Soc. Stud. Sci. 2009, 39, 363-394. [CrossRef]

19. Schmidt, J. Scare of insecure? The right to water and the ethics of global water governance. In The Right to Water: Politics, Governance and Social Struggles; Sultana, F., Loftus, A., Eds.; Earthscan: Abingdon, UK, 2012; pp. 94-109.

20. Castro, J.E. Poverty and citizenship: Sociological perspectives on water services and public-private participation. Geoforum 2007, 38, 756-771. [CrossRef]

21. Hellberg, S. Water, life and politics: Exploring the contested case of eThekwini municipality through a governmentality lens. Geoforum 2014, 56, 226-236. [CrossRef]

22. Von Schnitzler, A. Citizenship Prepaid: Water, Calculability, and Techno-Politics in South Africa. J. S. Afr. Stud. 2008, 34, 899-917. [CrossRef]

23. Kooy, M.; Bakker, K. Technologies of Government: Constituting Subjectivities, Spaces, and Infrastructures in Colonial and Contemporary Jakarta. Int. J. Urban. Reg. Res. 2008, 32, 375-391. [CrossRef]

24. Boelens, R.; Panfichi, A.; Guevara, A. Indigenous water Rights in the Andean countries: Struggles over resources and legitimacy. J. Water Law 2010, 20, 268-277.

25. Boelens, R. The Politics of Disciplining Water Rights. Dev. Chang. 2009, 40, 307-331. [CrossRef]

26. Meehan, K. Disciplining De Facto Development: Water Theft and Hydrosocial Order in Tijuana. Environ. Plan. D Soc. Space 2013, 31, 319-336. [CrossRef]

27. Renou, Y. Performance indicators and the new governmentality of water utilities in France. International Rev. Adm. Sci. 2017, 83, 378-396. [CrossRef]

28. Lefebvre, H. Everyday Life in the Modern World; Routledge: New York, NY, USA, 1984.

29. Lefebvre, H. Rhythmanalysis: Space, Time and Everyday Life; Continuum: London, UK, 2004.

30. Smith, N. Uneven Development: Nature, Capital and the Production of Space, Blackwell: Oxford, UK, 1984.

31. Jenkins, R. Pierre Bourdieu; Routledge: New York, NY, USA; London, UK, 1992.

32. Anand, N. Hydraulic City: Water and the Infrastructure of Citizenship in Mumbai; Duke University Press: Durham, NC, USA, 2017.

33. Bourdieu, P. The Logic of Practice; Polity Press: Cambridge, UK, 1990.

34. Lave, R. Bridging Political Ecology and STS: A Field Analysis of the Rosgen Wars. Ann. Assoc. Am. Geogr. 2012, 102, 366-382. [CrossRef]

35. Eichholz, M.; Van Assche, K.; Oberkircher, L.; Hornidge, A.-K. Trading capitals? Bourdieu, land and water in rural Uzbekistan. J. Environ. Plan. Manag. 2013, 56, 868-892. [CrossRef]

36. Sakdapolrak, P. Water Related Health Risk, Social Vulnerability and Pierre Bourdieu; UNU Institute for Environment and Human Security (UNU-EHS): Bonn, Germany, 2007.

37. Zimmer, A.; Sakdapolrak, P. The Social Practices of Governing: Analysing Waste Water Governance in a Delhi Slum. Environ. Urban. ASIA 2012, 3, 325-341. [CrossRef] 
38. Bourdieu, P.; Wacquant, L. An Invitation to Reflexive Sociology; The University of Chicago Press: Chicago, CA, USA, 1992.

39. Bourdieu, P. Outline of a Theory of Practice; Cambridge University Press: London, UK, 1977.

40. Berlant, L. Cruel Optimism; Duke University Press: Durham, NC, USA, 2007.

41. De Certeau, M. The Practice of Everyday Life; University of California Press: Berkeley, CA, USA, 1984.

42. Frow, J.A. Michel de Certeau and the practice of representation. Cult. Stud. 1991, 5, 52-60. [CrossRef]

43. Kooy, M. Developing Informality: Jakarta's urban waterscape. Water Altern. 2014, 7, 35-53.

44. Von Schnitzler, A. Democracy's Infrastructure: Techno-Politics and Protest after Apartheid; Princeton University Press: Princeton, NJ, USA, 2017.

45. Cory, D.; Rahman, T. Environmental justicie and enforcement of the safe drinking water act: The Arizona arsenic experience. Ecol. Econ. 2009, 68, 1825-1837. [CrossRef]

46. Acevedo-Guerrero, T. Water infrastructure: A terrain for studying nonhuman agency, power relations, and socioeconomic change. Wiley Interdiscip. Rev. Water 2018, 5, e1298. [CrossRef]

47. Furlong, K.; Kooy, M. Worlding Water Supply: Thinking Beyond the Network in Jakarta. Int. J. Urban. Reg. Res. 2017, 41, 888-903. [CrossRef]

48. Caldeira, T.; Holston, J. State and Urban Space in Brazil: From Modernist Planning to Democratic Interventions. In Global Assemblages: Technology, Politics, and Ethics as Anthropological Problems; Ong, A., Collier, S.J., Eds.; Blackwell: Malden, MA, USA, 2005; pp. 393-416.

49. Roitman, J. Fiscal Disobedience: An Anthropology of Economic regulation in Central Africa; Princeton University Press: Princeton, NJ, USA; Oxford, UK, 2005.

50. James, W. Pragmatism: An Old Way for Some New Ways of Thinking; Longmans, Green and Co.: New York, NY, USA, 1907.

51. Bridge, G. Reason in the City of Difference: Pragmatism, Communicative Action, and Contemporary Urbanism; Routledge: London, UK, 2005.

52. Varela, F.J. Ethical Know-How: Action, Wisdom, and Cognition; Stanford University Press: Palo Alto, CA, USA, 1999.

53. Allen, J. Pragmatism and power, or the power to make a difference in a radically contingent world. Geoforum 2008, 39, 1613-1624. [CrossRef]

54. Jones, O. Stepping from the wreckage: Geography, pragmatism and anti-representational theory. Geoforum 2008, 39, 1600-1612. [CrossRef]

55. Allen, J. Lost Geographies of Power; Blackwell: Malden, MA, USA, 2003.

56. Hommels, A. Unbuilding Cities: Obduracy in Urban Sociotechnical Change; The MIT Press: Cambridge, MA, USA; London, UK, 2008.

57. Hughes, T.P. The evolution of large technological systems. In The Social Construction of Technological Systems. New Directions in the Sociology and History of Technology; Bijker, W.E., Hughes, T.P., Pinch, T.J., Eds.; Cambridge University Press: Cambridge, UK, 1987; pp. 51-82.

58. Swyngedouw, E.A. Territorial Organization and the Space/Technology Nexus. Trans. Inst. Br. Geogr. 1992, 17, 417. [CrossRef]

59. Bear, L. Navigating Austerity: Currents of Debt Along a South Asian River; Stanford University Press: Stanford, CA, USA, 2015.

60. Dewey, J. Experience and Education; Collier Books: New York, NY, USA, 1938.

61. Hawkins, G. Packaging water: Plastic bottles as market and public devices. Econ. Soc. 2011, 40, 534-552. [CrossRef]

62. Kooy, M.; Walter, C.T. Towards A Situated Urban Political Ecology Analysis of Packaged Drinking Water Supply. Water 2019, 11, 225. [CrossRef]

63. Stoler, J. From curiosity to commodity: A review of the evolution of sachet drinking water in West Africa. Wiley Interdiscip. Rev. Water 2017, 4, e1206. [CrossRef]

64. Dewey, J. The Collected Works of John Dewey, 1882-1953; InteLex Corp. Southern Illinois University Press: Carbondale, IL, USA, 2003.

65. Schatzki, T.R. The Site of the Social: A Philosophical Account of the Constitution of Social Life and Change; Pennsylvania State University Press: University Park, PA, USA, 2002.

66. Latour, B. The Powers of Association. In Power, Action and Belief: A New Sociology of Knowledge? Law, J., Ed.; Routledge: London, UK, 1986; pp. 264-280. 
67. Cupples, J. Shifting Networks of Power in Nicaragua: Relational Materialisms in the Consumption of Privatized Electricity. Ann. Assoc. Am. Geogr. 2011, 101, 939-948. [CrossRef]

68. Meehan, K.M. Tool-power: Water infrastructure as wellsprings of state power. Geoforum 2014, 57, $215-224$. [CrossRef]

69. Furlong, K. STS beyond the "modern infrastructure ideal": Extending theory by engaging with infrastructure challenges in the South. Technol. Soc. 2014, 38, 139-147. [CrossRef]

70. Roca-Servat, D. Injusticias socioambientales en torno al agua y mineria gran escala: El caso de la ciudad de Arequipa, Peru. In Mineria, Agua y Justicia Social en los Andes; Perreault, T., Ed.; Centro de Estudios Regionales Andinos Bartolome de las Casas: Cuzco, Peru, 2014.

71. Roca-Servat, D. Unveiling Water (In) Justice in Arequipa: A Case Study of Mining Industry in Urban Space. Ph.D. Thesis, Arizona State University, Tempe, Arizona, 2012. Available online: https://repository.asu. edu/attachments/94106/content//tmp/package-SozXgm/RocaServat_asu_0010E_12153.pdf (accessed on 19 September 2019).

72. O'Reilly, K.; Louis, E. The toilet tripod: Understanding successful sanitation in rural India. Health Place 2014, 29, 43-51. [CrossRef]

73. Truelove, Y. (Re-)Conceptualizing water inequality in Delhi, India through a feminist political ecology framework. Geoforum 2011, 42, 143-152. [CrossRef]

74. Zwarteveen, M.; Ahmed, S.; Gautam, S.R. Diverting the Flow: Gender Equity and Water in South Asia; Zubaan: New Delhi, India, 2012.

75. Kleinman, A. What Really Matters: Living a Moral Life Amidst Uncertainty and Danger; Oxford University Press: Oxford, UK, 2006.

76. De Certeau, M. L'invention du Quotidien. 1. Arts de Faire; Gallimard: Paris, France, 1990.

77. Collier, S.J.; Lakoff, A. On Regimes of Living. In Global Assemblages: Technology, Politics, and Ethics as Anthropological Problems; Ong, A., Collier, S.J., Eds.; Blackwell: Malden, MA, USA, 2005; pp. 22-39.

78. Kohl, B. Privatization Bolivian style: A cautionary tale. Int. J. Urban. Reg. Res. 2004, 28, 893-908. [CrossRef]

79. Laurie, N.; Marvin, S. Globalisation, Neoliberalism, and Negotiated Development in the Andes: Water Projects and Regional Identity in Cochabamba, Bolivia. Environ. Plan. A: Econ. Space 1999, 31, 1401-1415. [CrossRef]

80. Perreault, T. From the Guerra Del Agua to the Guerra Del Gas: Resource Governance, Neoliberalism and Popular Protest in Bolivia. Antipode 2006, 38, 150-172. [CrossRef]

81. Gilligan, C. Woman's Place in Man's Life Cycle. Harv. Educ. Rev. 1979, 49, 431-446. [CrossRef]

82. Tronto, J.L. Moral Boundaries: A Political Argument for an Ethic of Care; Routledge: New York, NY, USA; London, UK, 1993.

83. Laugier, S. L'éthique comme politique de l'ordinaire. Multitudes 2009, 37, 80. [CrossRef]

84. Han, C. Life in debt. Times of care and violence in neoliberal Chile; University of California Press: Berkeley, CA, USA; Los Angeles, CA, USA, 2012.

85. Katz, C. Vagabond Capitalism and the Necessity of Social Reproduction. Antipode 2001, 33, 709-728. [CrossRef]

86. Popke, J. Geography and ethics: Everyday mediations through care and consumption. Prog. Hum. Geogr. 2006, 30, 504-512. [CrossRef]

87. Smith, S.J. States, markets and an ethic of care. Politi. Geogr. 2005, 24, 1-20. [CrossRef]

88. Lawson, V. Instead of Radical Geography, How About Caring Geography? Antipode 2009, 41, $210-213$. [CrossRef]

89. Acevedo-Guerrero, T.; Furlong, K.; Arias, J. Complicating neoliberalization and decentralization: The non-linear experience of Colombian water supply, 1909-2012. Int. J. Water Resour. Dev. 2015, 32, 172-188. [CrossRef]

90. Furlong, K. The Dialectics of Equity: Consumer Citizenship and the Extension of Water Supply in Medellín, Colombia. Ann. Assoc. Am. Geogr. 2013, 103, 1176-1192. [CrossRef]

91. Mol, A.; Moser, I.; Pols, A.J. Care in Practice: On Tinkering in Clinics, Homes and Farm; Transcript Verlag: Bielefeld, Germany, 2010.

92. De la Bellacasa, M.P. Ethical doings in naturecultures. Ethics Place Environ. 2010, 13, 151-169. [CrossRef]

93. Mol, A. The Logic of Care: Health and the Problem of Patient Choice; Routledge: London, UK, 2008.

94. Denis, J.; Pontille, D.; Denis, J. Material Ordering and the Care of Things. Sci. Technol. Hum. Values 2014, 40, 338-367. [CrossRef] 
95. Acevedo-Guerrero, T. Light is like water: Flooding, blackouts, and the construction of marginality in Barranquilla. Tapuya Latin Am. Sci. Technol. Soc.. (in press).

96. Tzul, G.T. Communal Strategies for Controlling Microfinance in Chuimeq'ena' Guatemala. South. Atl. Q. 2016, 115, 625-631. [CrossRef]

97. Gago, V. Neoliberalism from Below. Popular Pragmatics and Baroque Economies; Duke University Press: Durham, NC, USA, 2017.

98. Navarro, M.L. Luchas por lo Común. Antagonismo Social Contra el Despojo Capitalista de los Bienes Naturales en México; Bajo Tierra Ediciones: Ciudad de Mexico, Mexico, 2015.

99. Gutierrez-Aguilar, R.G.; Linsalata, L.; Trujillo, M.L.N.; Dinerstein, A.C. Producing the Common and Reproducing Life: Keys Towards Rethinking the Political. In Social Sciences for an Other Politics; Springer Science and Business Media LLC: Berlin, Germany, 2016; pp. 79-92.

100. Rivera-Cusicanqui, S. Video: Presentación del Libro "Un Mundo ch'ixi es Posible. Ensayos Desde un Presente en Crisis"; Editorial Tinta Limón: Buenos Aires, Argentina, 2018.

101. Monsalvo, M. Ch'ixinakax utxiwa: Una reflexión sobre prácticas y discursos descolonizadores de Silvia Rivera Cusicanqui. Íconos Revista de Ciencias Sociales 2013, 41, 173. [CrossRef]

102. Rivera-Cusicanqui, S. Un Mundo ch'ixi es Posible. Ensayos Desde un Presente en Crisis; Ediciones Tinta Limón: Buenos Aires, Argentina, 2018.

103. Rivera-Cusicanqui, S. Video: Historias Debidas VIII: Silvia Rivera Cusicanqui (capítulo completo) Buenos Aires; Canal Encuentro: Argentina, 2018.

104. Pazzarelli, F. Entrevista: Esas papitas me están mirando! Silvia Rivera Cusicanqui y la textura ch'ixi de los mundos. Revista de antropologia da UFSCar 2017, 9, 219-230.

105. Solway, J.S. Drought as a Revelatory Crisis: An Exploration of Shifting Entitlements and Hierarchies in the Kalahari, Botswana. Dev. Chang. 1994, 25, 471-495. [CrossRef]

106. Rivera-Cusicanqui, S. Video: Horizontes Politicos Comunitatios; Rompeviento TV: Mexico, 2015.

107. Gago, V.; Rivera-Cusicanqui, S. Video: Un Mundo ch'ixi es Posible. Ensayos Desde un Presente en Crisis; Tinta Limon: Buenos Aires, Argentina, 2018.

108. Yates, J.S.; Harris, L.M.; Wilson, N.J. Multiple ontologies of water: Politics, conflict and implications for governance. Environ. Plan. D Soc. Space 2017, 35, 797-815. [CrossRef]

109. Zwarteveen, M.; Kemerink-Seyoum, J.S.; Kooy, M.; Evers, J.; Guerrero, T.A.; Batubara, B.; Biza, A.; Boakye-Ansah, A.; Faber, S.; Cabrera Flamini, A.; et al. Engaging with the politics of water governance. WIREs Water 2017, 4, 1-9.

110. Bonelli, C.; Roca-Servat, D.; Bueno de Mesquita, M. The many natures of water in Latin-American neo-extractivist conflicts. Alternautas 2016, 3, 81-94.

111. Botero-Mesa, M. Prácticas de Derecho al Agua de la Mesa Interbarrial de Desconectados en el Territorio Hidrosocial El Faro, Medellín. ¿Una Alternativa al Desarrollo? Master's Thesis, Universidad Pontificia Bolivariana, Medellín, Colombia, 2019.

112. Parr, J. Local Water Diversely Known: Walkerton Ontario, 2000 and after. Environ. Plan. D Soc. Space 2005, 23, 251-271. [CrossRef]

113. Rivera-Cusicanqui, S. Video: Dialogue with Mayra Estévez and Fabiano Kueva; Centro Experimental Oído Salvaje: Quito, Ecuador, 2011.

114. Gutierrez-Aguilar, R. Los ritmos del Pachakuti Movilización y levantamiento popular-indígena en Bolivia (2000-2005); Tinta Limón: Buenos Aires, Argentina, 2008.

115. Marston, A.J. The Scale of Informality: Community-Run Water Systems in PeriUrban Cochabamba, Bolivia. Water Altern. 2014, 7, 72-88.

116. Roa-García, M.; Brown, S.; Roa-García, C. Jerarquía de vulnerabilidades de las organizaciones comunitarias de agua en Colombia (Hierarchy of Vulnerabilities of Community Water Organizations in Colombia). Gestión Ambiente 2015, 18, 51-79.

117. Roa-García, M.C. Environmental democratization and water justice in extractive frontiers of Colombia. Geoforum 2017, 85, 58-71. [CrossRef]

(C) 2019 by the authors. Licensee MDPI, Basel, Switzerland. This article is an open access article distributed under the terms and conditions of the Creative Commons Attribution (CC BY) license (http://creativecommons.org/licenses/by/4.0/). 